\title{
Kalp Yetersizliği Hastalarında Ürik Asit seviyeleri ile Etiyoloji arasındaki İlişkinin Değerlendirilmesi
}

Evaluation of the Relationship Between Uric Acid Levels and Etiology in Patients
With Heart Failure

\author{
Fatih GÜNGÖREN $^{1}{ }^{(D)}$, Feyzullah BEŞLi 1
}

1Harran Üniversitesi Tıp Fakültesi Kardiyoloji Anabilim Dalı , Şanlıurfa

Öz.

Amaç: Ürik asit, insanlarda pürin metabolizması sonucunda meydana gelen son üründür ve pek çok çalışmada kardiyovasküler hastalıklar ile ilişkisi incelenmiştir. Ancak, iskemik ve dilate kardiyomiyopati hastalarında serum ürik asit seviyelerinin değerlendirildiği çalışmalar sınırlıdır. Çalışmamızın amacı, iskemik (IKMP) ve dilate kardiyomiyopati (DKMP) hastalarında serum ürik asit seviyelerini karşılaş̧ırmaktır.

Materyal ve Metod: Bu çalışmaya kliniğimizde Ocak 2016 ile Haziran 2018 tarihleri arasında düşük ejeksiyonfraksiyonlu kalp yetersizliği nedeniyle yatmış olan 115 hasta ve yaş-cinsiyet eşleştirmesi yapılan 55 kontrol hastası alındı. DEFKY'li hastalar IKMP olanlar $(n=69)$ ve DKMP olan hastalar $(n=46)$ olarak iki gruba ayrıldı.

Bulgular: IKMP ve DKMP grupları arasında; cinsiyet, vücut kitle indeksi, kullanılan ilaçlar ve aritmi görülme sıklığı açısından anlamlı bir farklılık saptanmadı. Ancak, IKMP grubunda yaş, hipertansiyon, hiperlipidemi, koroner arter hastalığı (KAH) varlığı, ailede KAH öyküsü ve sigara içiciliği sıklığı anlamlı olarak daha fazla idi. Her iki grup, laboratuvar özellikleri açısından karşılaştırıldıklarında; IKMP grubunda ürik asit değerinin anlamlı olarak daha yüksek olduğu saptandı ( $6.9 \pm 1.9$ 'a karşın $6.3 \pm 1.2, p=0.029)$.

Sonuç: Çalışmamızda, IKMP'li kalp yetersizliği hastalarında serum ürik asit düzeyinin DKMP'li kalp yetersizliği hastalarına göre anlamlı olarak yüksek olduğu tespit edildi.

Anahtar kelimeler: Kalp yetersizliği, İskemik Kardiyomiyopati, Dilate Kardiyomiyopati, Ürik asit

\section{Abstract}

Background: Uric acid is the final product of purine metabolism in humans, and its relationship with cardiovascular diseases has been investigated in many studies. However, there are limited studies evaluating serum uric acid levels in patients with ischemic and dilated cardiomyopathy. The aim of this study is to compare serum uric acid levels in patients with ischemic (ICMP) and dilated cardiomyopathy (DCMP).

Materials and Methods: A total of 115 patients with low ejection fraction heart failure who were admitted to our clinic between January 2016 and June 2018 and 55 age-sex matched control were included in this study. Patients with low ejection fraction heart failure were divided into two groups as follows: ICMP $(n=$ 69) and DCMP $(n=46)$.

Results: There was no statistically significant difference between ICMP and DCMP groups in terms of gender, body mass index, used drugs and frequency of arrhythmias. However, age, the frequency of hypertension, hyperlipidemia, coronary artery disease (CAD), history of familial CAD and smoking were significantly higher in ICMP group. When both groups were compared in terms of laboratory characteristics, it was found observed that uric acid value was significantly higher in ICMP group (6.9 \pm 1.9 vs. $6.3 \pm 1.2, p=0.029$ ).

Conclusion: In our study, it was found that serum uric acid level was significantly higher in heart failure patients with ICMP compared to patients with DCMP.

Keywords: Heart failure, Ischemic Cardiomyopathy, Ischemic Cardiomyopathy, Uric acid
Sorumlu Yazar I

Corresponding Author

Dr. Fatih Güngören

Harran Üniversitesi Tıp Fakültesi

Kardiyoloji Anabilim dalı,

Osman bey kampüsü,

Haliliye / Şanlıurfa, Türkiye

Posta kodu: 63000

e mail: fatihgungorendr@gmail.com

Tel: 05357954580

Fax: 0 (414) 3183192

Geliş tarihi / Received:

05.11.2019

Kabul tarihi / Accepted: 25.11.2019

DOI: 10.35440/hutfd.642972 


\section{Giriş}

Kalp yetersizliği $(\mathrm{KY})$, normal dolum basınçlarına rağmen (veya sadece artmış dolum basınçları pahasına), kalbin dokuların metabolik intiyaçlarını karşılayacak ölçüde oksijen sunamamasına yol açan, kardiyak, yapısal veya işlevsel bozukluk şeklinde tanımlanmaktadır (1). Gelişmiş ülkelerde toplumun yaklaşık \%1-2'sinde KY'ye rastlanmakta ve KY'nin prevalansı 70 yaş ve üzerindeki bireylerde $\geq \% 10$ 'a kadar yükselmektedir (2). KY, düşük ejeksiyon fraksiyonlu ve korunmuş ejeksiyon fraksiyonlu KY olarak sınıflandırımakta olup, büyük çoğunluğunu düşük ejeksiyon fraksiyonlu kalp yetersizliği (DEFKY) oluşturur. DEFKY' nin pek çok sınıflandırması olup, en çok kabul göreni koroner arter hastalığı (KAH)' a bağlı iskemik kardiyomiyopati (IKMP) ve non-iskemik/dilate (DKMP) şeklindeki sınıflandırmadır $(1,3,4)$. DEFKY hastalarının yaklaşık olarak üçte ikisini oluşturan IKMP, KAH' ın sonucu olarak ortaya çıkarken, DKMP ise geçirilmiş viral enfeksiyonlar (teşhis edilebilmiş veya edilememiş), alkolün kötüye kullanımı, kemoterapi (örn. doksorubisin veya trastuzumab) ve 'idiyopatik' dilate kardiyomiyopati (sebebi bilinmemesine rağmen bazı olgularda genetik temelli olabilir) gibi iskemik kökenli olmayan sebeplere bağlı ortaya çıkmaktadır $(3,5)$.

DEFKY'li hastaların tanı, takip ve tedaviye yanıtlarının değerlendirmesinde birçok biyokimyasal parametreler kullanilmakta olup, bu parametrelerden bazıları DEFKY etiyolojisine göre daha fazla önem kazanabilmektedir. Ürik asit, insanlarda pürin metabolizması sonucunda meydana gelen son ürün olup kardiyovasküler hastalıklar ile ilişkisi pek çok çalışmada incelenmiştir (6-9). KAH, hipertansiyon (HT), akut koroner sendrom ve atriyal fibrilasyon gibi bir çok kardiyovasküler hastalıkta yüksek ürik asit düzeylerinin kötü sonuçlarla ilişkili olduğu bildirilmiştir $(8,10)$. Son yillarda DEFKY'de de ürik asit seviyelerinin yüksek olduğu saptanmış olup, bu durumun önemi üzerine giderek artan bir ilgi mevcuttur (11). Çalışmamızın amacl, DEFKY etiyolojisi ile (iskemik ve noniskemik/dilate) ürik asit düzeyi arasındaki ilişkiyi incelemektir.

\section{Materyal ve Metot \\ Hasta seçimi ve tanımı}

Çalışmaya Harran Üniversitesi Tıp Fakültesi Kardiyoloji Kliniğine Ocak 2016 ile Haziran 2018 tarihleri arasında; dekompanse DEFKY nedeniyle yatmış olan 115 hasta ve yaş ve cinsiyet eşleştirmesi yapılan DEFKY tanısı olmayan 55 kontrol hastası alındı. DEFKY tanısı, 2016 yılı Avrupa kardiyoloji derneğinin kalp yetersizliği kılavuzuna göre belirlendi: ejeksiyon fraksiyonu $<\% 40$ altında olması ve objektif kalp yetersizliği belirti \pm bulgularının olması (1). Belirtilen tarihlerde DEFKY tanısı ile takip edilen hastalar çalışmaya dahil edildi ve hastalar iki gruba ayrıldı: iskemik kardiyomiyopati (IKMP) olanlar $(n=69)$ ve non- islemik/dilate kardiyomiyopati (DKMP) olan hastalar $(n=46)$. IKMP, DEFKY ile beraber etiyolojide bilinen KAH varlığı veya yapılan koroner anjiyografide koroner arterlerde anlamlı darık oluşu şeklinde tanımlandı $(1,3)$. DKMP tanısı, KAH yokluğunda DEFKY varlığı şeklinde tanımlandı $(1,3)$. HT tanısı sistolik tansiyon değerinin $\geq 140 \mathrm{mmHg}$ ve/veya diyastolik tansiyon değerinin $\geq 90$ $\mathrm{mmHg}$ olması ve/veya hastanın tansiyon ilacı kullanıyor olması şeklinde tanımlandı. Hiperlipidemi (HL) tanısı açlık kolesterol düzeyleri $>200 \mathrm{mg} / \mathrm{DI}$ olması veya açlık trigliserit seviyeleri iki kez $200 \mathrm{mg} / \mathrm{dL}$ ' den fazla olması veya hiperlipidemi için tedavi alıyor olması şeklinde tanımlandı. Çalışma için yerel etik kurul onayı Harran Üniversitesi etik kurulundan alındı.

18 yaşından küçük olan hastalar, Gut hastalığı tanısı olanlar, gebeler, şiddetli karaciğer hastalığı olanlar, akut veya kronik böbrek yeteresizliği olanlar, aktif enfeksiyonu olanlar, kronik enflamatuvar hastalığı olanlar, malignitesi olanlar ile hastaneye yatışında akut koroner sendromlar ve pulmoner emboli tanısı konan hastalar çalışma dışı bırakıldı.

Hastalar ve kontrol grubundan başvuru sırasında kan örnekleri alındı. Kan örnekleri alındığı gün biyokimyasal parametreler, serum lipit ölçümü ve tam kan sayımı yapıdı.

\section{Ekokardiyografik değerlendirme}

Tüm ekokardiyografik ölçümler Amerikan Ekokardiyografi Derneği' nin kılavuzuna göre, hasta verilerinden haberdar olmayan deneyimli bir kardiyolog tarafından değerlendirildi. Ekokardiyografik görüntüler, Vivid S5 model ekokardiyografi cihazı (General Electrics, Vivid S5 ekokardiyografi, Milwaukee, WI) kullanılarak yapıldı ve her hasta için görüntüler kaydedildi. Elde edilen kayıtlar üzerinden ölçümler yapıldı. Her hasta için sol ventrikül diyastolik sonu çapı (LVEDD), sol ventrikül sistolik sonu çapı (LVESD), interventriküler septum kalınlığı (IVST) ve arka duvar kalınlığı (PWT) ölçüldü. Sol ventrikül ejeksiyon fraksiyonu (EF), apikal 2 ve 4 boşluk görüntülerde modifiye Simpson yöntemi kullanılarak elde edildi. (12).

\section{İstatistiksel analiz}

Verilerin analizinde SPSS 22 (Chicago, IL, ABD) paket programı kullanılmıştır. Tüm verilerin normal dağılıp dağılmadığını test etmek için Kolmogorov-Smirnov testi kullanıldı. Kategorik değişkenler sayı (\%) olarak, sayısal değişkenler ise dağılım özelliğine göre ortalama (standart sapma) veya median (25. - 75. çeyrekler) şeklinde verildi. Normal dağılım gösteren sayısal verilerin karşılaştıııması için Student $t$ testi, normal dağılım göstermeyen sayısal veriler için Mann-Whitney $U$ testi kullanıldı. Kategorik değişkenlerin karşılaşıııımasında ise ki kare testi kullanıldı. P değerinin 0.05 ' in altında olması istatistiksel anlamlıIık olarak kabul edildi. 


\section{Bulgular}

Çalışmaya alınan DEFKY hastalarını ve kontrol grubuna ait bazal demografik özellikler Tablo 1' de gösterilmektedir. DEFKY grubu ile kontrol grubu arasında yaş, cinsiyet, vücut kitle indeksi (VKI), HT ve sigara içimi açısından anlamlı bir farklılık tespit edilmedi. Ancak, DEFKY grubunda KAH sıklığı $(p<0.001)$ ve elektrokardiyografide sinüs dışı ritimler daha fazla idi $(p<0.001)$. Ek olarak, DEFKY grubunun ejeksiyon fraksiyonu kontrol grubu ile karşılaştırıldığında anlamlı olarak daha düşük idi (29.0 \pm 8.6'ya karşın $63.5 \pm 3.8, p<0.001$ ).

Tablo 1. Çalışmaya dâhil edilen hastaların bazal demografik özellikleri

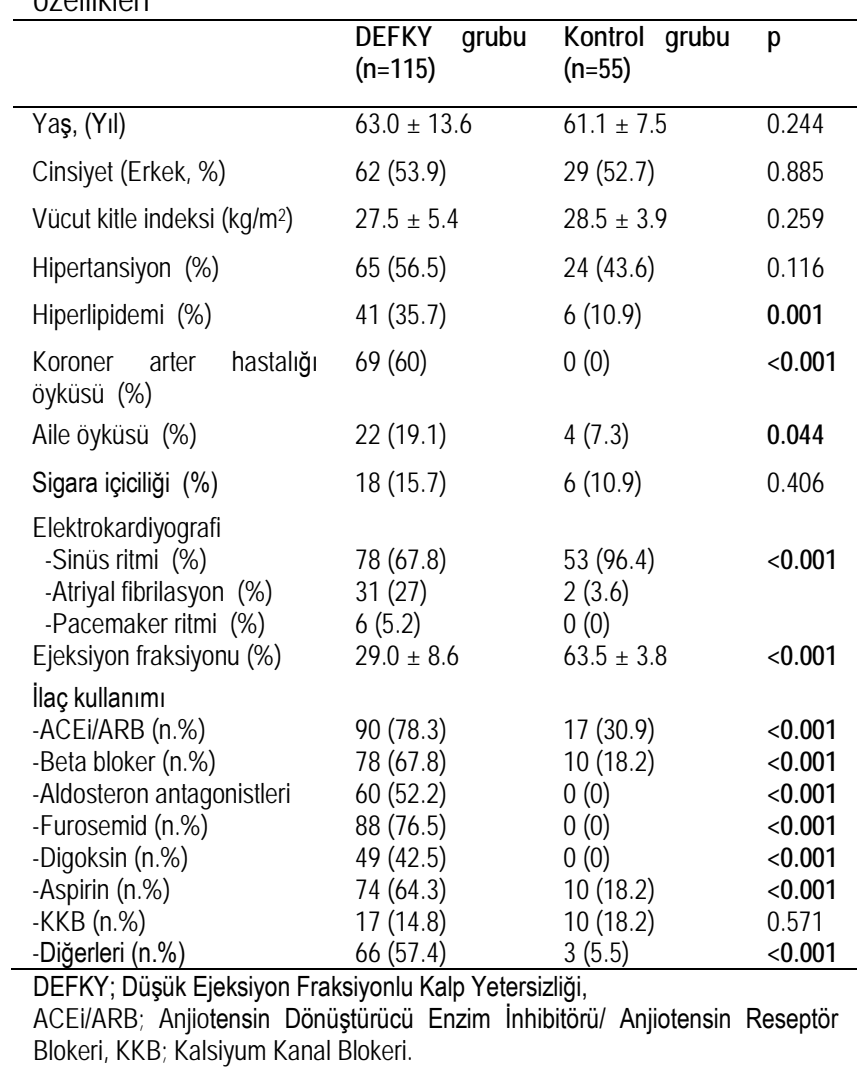

DEFKY hastalarının ve kontrol grubunun laboratuvar sonuçları Tablo 2' de özetlenmiştir. DEFKY grubunda; kreatinin, glomerüler filtrasyon hızı (GFR), aspartat amino-transferaz (AST), C-reaktif protein ve ürik asit düzeyleri kontrol grubuna göre anlamlı olarak daha yüksek iken; sodyum ( $\mathrm{Na}$ ), total kolesterol, LDL kolesterol, HDL kolesterol, trigliserid ve hemoglobin düzeyleri ise anlamlı olarak daha düşük idi.
Tablo 2. Çalışmaya alınan hastaların biyokimyasal özellikleri

\begin{tabular}{llll}
\hline & DEFKY (n=115) & Kontrol (n=55) & $\mathbf{p}$ \\
\hline Kan şekeri $(\mathrm{mg} / \mathrm{dL})$ & $91.4 \pm 11.9$ & $91.1 \pm 8.3$ & 0.882 \\
Kreatinin $(\mathrm{mg} / \mathrm{dl})$ & $0.96 \pm 0.2$ & $0.76 \pm 0.1$ & $<0.001$ \\
GFR mL/min/1.73 m2) & $86(63-99)$ & $98(83-114)$ & $<0.001$ \\
Sodyum (mg/dL) & $135.6 \pm 4.7$ & $140.0 \pm 1.8$ & $<0.001$ \\
Potasyum (mg/dL) & $4.2 \pm 0.5$ & $4.3 \pm 0.4$ & 0.470 \\
AST (mg/dL) & $20(16-30)$ & $18(14-21)$ & 0.003 \\
ALT (mg/dL) & $18(13-28)$ & $16(12-21)$ & 0.101 \\
Total kolesterol (mg/dL) & $159(128-194)$ & $202(188-228)$ & $<0.001$ \\
& & & $<0.001$ \\
LDL kolesterol (mg/dL) & $100(82-126)$ & $124(112-152)$ & \\
& & & $<0.001$ \\
HDL kolesterol (mg/dL) & $34(28-42)$ & $44(39-55)$ & $<0.0001$ \\
Trigliserid (mg/dL) & $98(79-142)$ & $145(90-177)$ & 0.004 \\
Hemoglobin (g/dL) & $12.5 \pm 1.8$ & $14.0 \pm 0.8$ & $<0.001$ \\
Urik Asit (mg/dL) & $6.7 \pm 1.7$ & $5.7 \pm 1.2$ & $<0.001$ \\
C-reaktif protein (mg/L) & $1.06(0.82-1.06)$ & $1.06(0.33-1.06)$ & $<0.001$ \\
\hline
\end{tabular}

DEFKY Düşük Ejeksiyon Fraksiyonlu Kalp Yetersizliği,

GFR; Glomerüler Filtrasyon Hızı, AST; Aspartat Aminotransferaz,

ALT; Alanin Aminotransferaz,

LDL kolesterol; Düşük Dansiteli Lipoprotein Kolestreolü,

HDL kolesterol; Yüksek Dansiteli Lipoprotein Kolestreolü.

DEFKY hastaları, iskemik kardiyomiyopati $(n=69)$ ve noniskemik/dilate kardiyomiyopati $(n=46)$ olarak iki gruba ayrıldı. Her iki grubun bazal demografik özellikleri Tablo 3'te gösterilmektedir. IKMP ve DKMP grupları arasında, cinsiyet, VKi, kullanılan ilaçlar ve kardiyak ritm açısından istatistiksel olarak fark saptanmadı. Ancak, IKMP hastalarının DKMP hastalarına göre yaşlı olduğu görüldü (65.8 \pm 10.9'a karşın $58.8 \pm 16.1, P=0.012)$. Ek olarak, HT ( $p=$ $0.002), H L(p=0.032), K A H$ varlığı $(p<0.001)$, ailede KAH öyküsü $(p=0.028)$ ve sigara içiciliği sıkığı da $(p=$ 0.019) İKMP grubunda anlamlı olarak daha fazla saptandı. IKMP grubunun ejeksiyon fraksiyonunun DKMP grubuna göre daha yüksek olduğu görüldü $(30.5 \pm 8.6$ 'ya karşın $26.7 \pm 8.0, p=0.021$ ).

IKMP grubu ile DKMP grubu laboratuvar özellikleri Tablo 4'te gösterilmektedir. DKMP grubu ile karşılaştııldığında, serum ürik asit seviyesinin IKMP grubunda anlamlı olarak daha yüksek olduğu saptandı $(6.9 \pm 1.9$ 'a karşın $6.3 \pm$ $1.2, p=0.029)$ (Şekil 1).

\section{Tartışma}

Çalışmamızda DEFKY hastalarında ürik asit seviyesinin etiyolojiye göre değişiklik gösterdiğini ve IKMP grubunda DKMP grubuna göre anlamlı olarak daha fazla yükselmiş olduğunu tespit ettik.

DEFKY, gelişmiş ülkelerde toplumun yaklaşık olarak \%12 'sinde görülen, ancak prevalansı yaşla birlikte artan ve 70 yaş üzerindeki bireylerde sıklı̆̆ı $\geq \% 10$ 'a kadar yükse- 
len kötü prognozlu bir hastalıktır (2). DEFKY gelişiminde birçok risk faktörünün rol oynadığı bilinmektedir $(1,2)$. Çalışmamızda da, kontrol grubu ile arşılaştırılı̆ğında DEFKY grubunda total kolesterol, LDL kolesterol, HDL kolesterol ve trigliserid düzeyi arasında anlamlı bir farkılıı mevcuttu. Bunun nedeni, DEFKY grubunda aterosklerotik kalp hastalığı nedeniyle statin tedavisi alan hastaların bulunması ve kalp yetersizliği olan hastalarda görülen beslenme bozuklukları ile açıklanabilir. Yine DEFKY grubunda hemoglobin düzeyinin kontrol grubuna göre daha düşük olduğu saptanmıştır. Bu durum kalp yetersizliğinde; artmış olan inflamatuvar aktivasyon, görülen beslenme bozuklukları, renal yetmezlik, hemodilüsyon, bozulmuş kemik iliği fonksiyonu, anjiotensin dönüştürücü enzim inhibitörü (ACEI) veya anjiyotensin reseptör blokeri (ARB) kullanımı ve gastrointestinal sistemden (GIS) gizli kanamalar ile ilişkilendirilebilir (1). Çalışmamızda bunlara ek olarak, DEFKY grubunda böbrek fonksiyonlarının kontrol grubuna göre nispeten daha bozuk olduğu saptanmıştır. Bu durum da, DEFKY hastalarında kardiyak debinin ve efektif dolaşan volümün azalması ve artmış kompansatuvar mekanizmaların yanı sıra nefrotoksik ilaçların etkisi ile böbrek fonksiyonların zaman içerisinde bozulmasına neden olması ile açıklanabilir (2-5).

DEFKY çeşitli etiyolojik nedenlere bağlı ortaya çıkabilmektedir. Bu etiyolojik nedenlere göre DEFKY' nin tanı, takip, tedavi ve prognozu farklılık arz edebilmektedir. DEFKY, temel olarak 2 ana alt gruba ayrılır: DKMP ve IKMP. Yapılan çalışmalarda, bu iki temel grup arasında hastaların demografik özellikleri açısından bazı farklılıklar mevcut olduğu gösterilmiştir. Özellikle, KAH için temel risk faktörleri olarak kabul edilen ileri yaş, $H T, H L$, ailede $\mathrm{KAH}$ öyküsü ve aktif sigara içiciliği gibi durumlar IKMP grubunda daha fazla görülmektedir (1-2). Çalışmamızda da, IKMP grubunda KAH için temel risk faktörlerinin DKMP grubuna göre anlamlı olarak daha fazla saptanmış olması literatür ile uyumludur.

DKMP ve IKMP hastalarında tanı, takip ve ciddiyetinin değerlendirilmesi amacıyla birçok biyokimyasal parametre araştııımıştır. Son dönemde, gerek kalp yetersizliği gerekse de diğer kardiyovasküler hastalıkların patogenezinde ürik asitin bir risk faktörü olabileceği tartışılmaktadır. Ürik asitin reaktif oksijen radikallerinin artmasına, vasküler düz kas hücre proliferasyonuna ve nitrik oksit üretiminin azalmasına neden olarak vasküler inflamasyona ve endotelyal disfonksiyona neden olduğu gösterilmiştir (13). Artmış ürik asit seviyesinin neden olduğu reaktif oksijen radikallerinin myokard fonksiyonlarında bozulma yaptığı insan ve hayvan deneylerinde gösterilmiştir (14-17).
Tablo 3. Kalp yetersizliği nedenine göre hastaların demografik özellikleri

\begin{tabular}{|c|c|c|c|}
\hline & $\begin{array}{l}\text { Dilate } \\
\text { kardiyomiyopati } \\
(n=46)\end{array}$ & $\begin{array}{l}\text { İskemik } \\
\text { kardiyomiyopati } \\
(\mathrm{n}=69)\end{array}$ & $p$ \\
\hline Yaş, (Yıl) & $58.8 \pm 16.1$ & $65.8 \pm 10.9$ & 0.012 \\
\hline Cinsiyet (Erkek, \%) & $22(47.5)$ & $40(58)$ & 0.285 \\
\hline $\begin{array}{l}\text { Vücut kitle indeksi } \\
\left(\mathrm{kg} / \mathrm{m}^{2}\right)\end{array}$ & $28.3 \pm 6.3$ & $27 \pm 4.5$ & 0.223 \\
\hline Hipertansiyon (\%) & $18(39.1)$ & $47(68.1)$ & 0.002 \\
\hline Hiperlipidemi (\%) & $11(23.9)$ & $30(43.5)$ & 0.032 \\
\hline $\begin{array}{l}\text { Koroner arter hastalığı } \\
\text { öyküsü (\%) }\end{array}$ & $0(0)$ & $69(100)$ & $<0.001$ \\
\hline Aile öyküsü (\%) & $4(8.7)$ & $18(26.1)$ & 0.028 \\
\hline Sigara içiciliği (\%) & $4(8.7)$ & $14(20.3)$ & 0.019 \\
\hline $\begin{array}{l}\text { Elektrokardiyografi } \\
\text {-Sinüs ritmi (\%) } \\
\text {-Atriyal fibrilasyon (\%) } \\
\text {-Pacemaker ritmi (\%) }\end{array}$ & $\begin{array}{l}31(67.4) \\
12(26.1) \\
3(6.5)\end{array}$ & $\begin{array}{l}47(68.1) \\
19(27.5) \\
3(4.3)\end{array}$ & 0.872 \\
\hline Ejeksiyon fraksiyonu (\%) & $26.7 \pm 8.0$ & $30.5 \pm 8.6$ & 0.021 \\
\hline İlaç kullanımı & & & \\
\hline -ACEi/ARB (n.\%) & $35(76.1)$ & $55(79.7)$ & 0.644 \\
\hline -Beta bloker (n.\%) & $36(78.3)$ & $42(60.9)$ & 0.050 \\
\hline -Aldosteron antagonistle- & $27(58.7)$ & $33(47.8)$ & 0.253 \\
\hline ri & $38(82.6)$ & $50(72.5)$ & 0.209 \\
\hline -Furosemid (n.\%) & $19(41.3)$ & $30(43.5)$ & 0.817 \\
\hline -Digoksin (n.\%) & $25(54.3)$ & $49(71)$ & 0.687 \\
\hline -Aspirin (n.\%) & $5(10.9)$ & $12(17.4)$ & 0.334 \\
\hline -KKB (n.\%) & $24(52.2)$ & $42(60.9)$ & 0.356 \\
\hline
\end{tabular}

ACEi/ARB; Anjiotensin Dönüştürücü Enzim İnhibitörü/ Anjiotensin Reseptör Blokeri,

KKB; Kalsiyum Kanal Blokeri.

Yapılan birçok epidemiyolojik çalışmada, artmış serum ürik asit düzeyleri ile kardiyovasküler olay gelişimi ve mortalite arasında bir ilişki olduğu ortaya konmuştur (8, 10). Ek olarak, artmış ürik asit seviyelerinin kalp yetersizliği olan hastalarda da bağımsız bir prognostik faktör olduğu gösterilmiştir (18). Yüksek serum ürik asit seviyelerinin, orta ve ciddi kalp yetersizliği olan hastalarda daha kötü prognoz ile ilişkili olduğu bildirilmiştir $(19,20)$. Khan ve arkadaşlarının yapmış olduğu bir çalışmada, kalp yetersizliği olmayan hastalara göre, DEFKY olan hastalarda serum ürik asit seviyeleri anlamlı olarak daha yüksek olduğu görülmüştür (11). Biz de literatür ile uyumlu olarak, çalışmamızda DEFKY hastalarında kontrol grubuna göre ürik asit seviyelerinin anlamlı olarak daha yüksek olduğunu tespit ettik. Tüm bu bulgular beraber değerlendirildiğinde, DEFKY hastalarında serum ürik asit seviyesinin yükseldiği ve kötü prognoz ile ilişkili olduğu söylenebilir. Çalışmamızda DEFKY hastalarında artmış CRP düzeyleri ile beraber ürik düzeylerinin daha yüksek saptanmış olması, DEFKY'li hastalarda yaygın inflamasyonun tetiklendiği düşündürmektedir.

Serum ürik asit seviyesi ile $\mathrm{KAH}$ arasındaki ilişkiyi inceleyen pek çok çalışma vardır. Patetsios ve ark. bir çalışma$\mathrm{da}$, aterosklerotik damarlarda ürik asit seviyesinin kontrol grubuna göre daha yüksek olduğunu saptamışlardır (21). 
Tablo 4. Kalp yetersizliği nedenine göre hastaların laboratuvar özellikleri

\begin{tabular}{|c|c|c|c|}
\hline & $\begin{array}{l}\text { Dilate } \\
\text { kardiyomiyopati } \\
(n=46)\end{array}$ & $\begin{array}{l}\text { İskemik } \\
\text { kardiyomiyopati } \\
(n=69)\end{array}$ & $\mathrm{p}$ \\
\hline Kan şekeri (mg/dL) & $89.5 \pm 10.7$ & $92.7 \pm 12.5$ & 0.152 \\
\hline Kreatinin (mg/dl) & $0.9 \pm 0.1$ & $1.0 \pm 0.2$ & 0.112 \\
\hline GFR $\mathrm{mL} / \mathrm{min} / 1.73 \mathrm{~m} 2$ ) & $93(71-103)$ & $89(58-94)$ & 0.226 \\
\hline Sodyum (mg/dL) & $135.8 \pm 4.5$ & $135.4 \pm 4.8$ & 0.611 \\
\hline Potasyum (mg/dL) & $4.3 \pm 0.5$ & $4.2 \pm 0.5$ & 0.499 \\
\hline AST (mg/dL) & $24(16-35)$ & $20(16-25)$ & 0.058 \\
\hline ALT (mg/dL) & $21(14-38)$ & $16(12-22)$ & 0.078 \\
\hline Total kolesterol (mg/dL) & 168 (130-199) & $158(126-193)$ & 0.463 \\
\hline LDL kolesterol (mg/dL) & $104(81-133)$ & $100(82-123)$ & 0.638 \\
\hline HDL kolesterol (mg/dL) & $36(27-43)$ & $33(28-40)$ & 0.340 \\
\hline Trigliserid (mg/dL) & $97(78-139)$ & $100(80-145)$ & 0.681 \\
\hline Hemoglobin (g/dL) & $12.8 \pm 1.6$ & $12.3 \pm 1.9$ & 0.143 \\
\hline Ürik Asit (mg/dL) & $6.3 \pm 1.2$ & $6.9 \pm 1.9$ & 0.029 \\
\hline
\end{tabular}

GFR; Glomerüler Filtrasyon Hızı,

AST; Aspartat Aminotransferaz,

ALT; Alanin Aminotransferaz,

LDL kolesterol; Düşük Dansiteli Lipoprotein Kolestreolü,

HDL kolesterol; Yüksek Dansiteli Lipoprotein Kolestreolü.

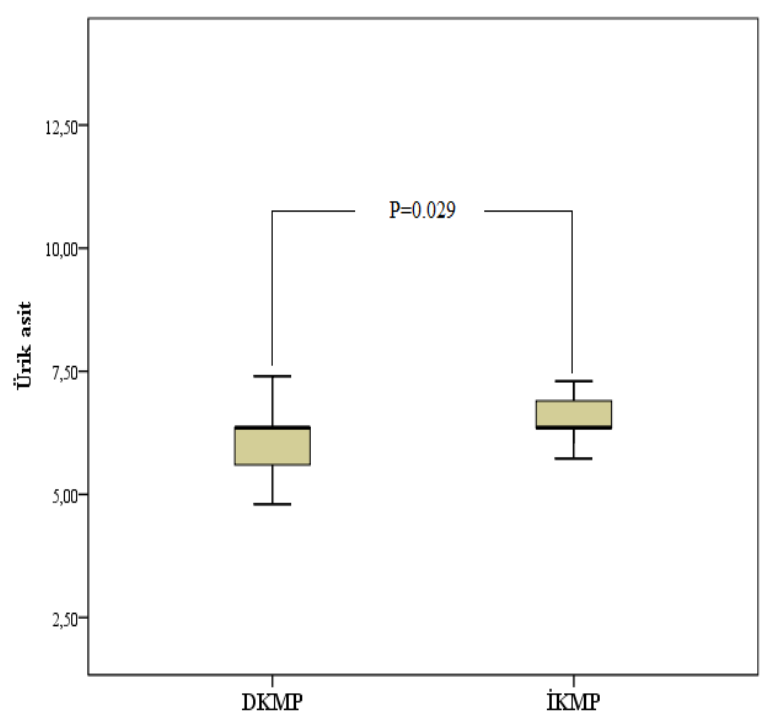

Şekil 1: IKMP ve DKMP gruplarında ürik asit seviyelerinin karşılaştırılması

Dahası, ürik asitin KAH ciddiyeti ile de ilişkisi rapor edilmiştir $(22,23)$. Biz de çalışmamızda $\mathrm{KAH}$ olup kalp yetersizliği gelişen IKMP grubunda serum ürik asit seviyesini, $\mathrm{KAH}$ olmayıp kalp yetersizliği gelişen DKMP grubuna göre anlamlı daha yüksek bulduk. Bu bulgular, IKMP hastalarında artmış ürik asit seviyelerinin nedeninin kalp yetersizliğine ek olarak altta yatan KAH' in oluşturmuş olduğu inflamasyon da olabileceğini düşündürmektedir. Çalışmamız, IKMP ve DKMP hastalarında serum ürik asit seviyelerinin anlamlı olarak farklı olduğunu göstermesi açısından önemli bir çalışmadır.

Serum ürik asit seviyesine özellikle tiyazid grubu diüretikler olmak üzere birçok ilaç etki edebilmektedir (24). Bizim çalışmamızdaki IKMP ve DKMP grubundaki hastaların ilaçları arasından istatistiksel olarak bir anlam olmayışı olası bir ilaç etkisini azaltmıştır.

Çalışmamızın bir takım kısıtılıkları mevcuttur. Öncelikle, çalışmamızın tek merkezde kısıtlı hasta sayısı ile yapıımış gözlemsel bir çalışma olması en büyük kısıtlıı̆̆ıydı. Ayrıca hastaların takip verilerinin olmayışı da diğer bir kısıtıllğıdır. Bunların dışında tedavi sonrasında ürik asit düzeylerindeki değişikliklerin değerlendirilmesi çalışmayı daha ilgi çekici hale getirebilirdi.

Sonuç olarak, ürik asit biyokimaysal analizler ile kolaylıkla elde edilebilen ucuz ve basit bir inflamatuvar parametredir. Bu çalışmada, IKMP 'li kalp yetersizliği hastalarında DKMP'li kalp yetersizliği hastalarına göre serum ürik asit düzeyinin anlamlı olarak daha yüksek olduğu tespit edilmiştir.

\section{Kaynaklar}

1. Ponikowski P, Voors AA, Anker SD, Bueno H, Cleland JGF, Coats AJS, et al. ESC Scientific Document Group. 2016 ESC Guidelines for the diagnosis and treatment of acute and chronic heart failure: The Task Force for the diagnosis and treatment of acute and chronic heart failure of the European Society of Cardiology (ESC)Developed with the special contribution of the Heart Failure Association (HFA) of the ESC. Eur Heart J. 2016 14;37(27): 2129-200.

2. Redfield MM, Jacobsen SJ, Burnett JC, Mahoney DW, Bailey KR, Rodeheffer RJ. Burden of systolic and diastolic ventricular dysfunction in the community: appreciating the scope of the heart failure epidemic. JAMA. 2003;289:194-202.

3. Yancy CW, Jessup M, Bozkurt B, Butler J, Casey DE Jr, Colvin MM, et al. 2017 ACC/AHA/HFSA Focused Update of the 2013 ACCF/AHA Guideline for the Management of Heart Failure: A Report of the American College of Cardiology/American Heart Association Task Force on Clinical Practice Guidelines and the Heart Failure Society of America J Card Fail. 2017;23(8):628-51.

4. Baig K, Mahon N, McKenna WJ, Caforio AL, Bonow RO, Francis GS, et al. The pathophysiology of advanced heart failure. Am Heart J. 1998;135:216-30.

5. Braunwald E. Congestive Heart Failure: a half century perspective. Eur Heart J 2001;22: 825-36.

6. Gertler MM, Garn SM, Levine SA. Serum uric acid in relation to age and AQ5 physique in health and in coronary heart disease. Ann Intern Med. 1951;34:1421-31.

7. Verdecchia P, Schillaci G, Reboldi G, Santeusanio F, Porcellati C, Brunetti P. Relation between serum uric acid and risk of cardiovascular disease in essential hypertension. The PIUMA study. Hypertension. 2000;36:1072-8.

8. Fang J, Alderman $\mathrm{MH}$. Serum uric acid and cardiovascular mortality the NHANES I epidemiologic follow-up study, 1971-1992. National Health and Nutrition Examination Survey. JAMA. 2000; 283:2404-10. 9. Liese AD, Hense HW, Löwel H, Döring A, Tietze M, Keil U. Association of serum uric acid with all-cause and cardiovascular disease mortality and incident myocardial infarction in the MONICA Augsburg cohort. World Health Organization Monitoring Trends and Determi- 
nants in Cardiovascular Diseases. Epidemiology. 1999;10: 391-7.

10. Baker JF, Krishnan E, Chen L, Schumacher HR. Serum uric acid and cardiovascular disease: recent developments, and where do they leave us. Am J Med. 2005;118:816-26.

11. Khan A, Shah MH, Khan S, Shamim U, Arshad S. Serum Uric Acid level in the severity of Congestive Heart Failure (CHF). Pak J Med Sci. 2017;33(2):330-4.

12. Lang RM, Badano LP, Mor-Avi V, Afilalo J, Armstrong A, Ernande $\mathrm{L}$, et al. Recommendations for cardiac chamber quantification by echocardiography in adults: an update from the American Society of Echocardiography and the European Association of Cardiovascular Imaging. J Am Soc Echocardiogr. 2015 28(1):1-39.e14.

13. Feig DI, Kang DH, Johnson RJ. Uric acid and cardiovascular risk. N Engl J Med. 2008;359(17):1811-21.

14. Ogino K, Kato M, Furuse $Y$, Kinugasa $Y$, Ishida K, Osaki S, et al. Uric acid-lowering treatment with benzbromarone in patients with heart failure: a double-blind placebo-controlled crossover preliminary study. Circ Heart Fail. 2010;3(1):73-81.

15. Amado LC, Saliaris AP, Raju SV, Lehrke S, St John M, Xie J, et al. Xanthine oxidase inhibition ameliorates cardiovascular dysfunction in dogs with pacing-induced heart failure. J Mol Cell Cardiol. 2005 39(3):531-6.

16. Minhas KM, Saraiva RM, Schuleri KH, Lehrke S, Zheng M, Saliaris AP, et al. Xanthine oxidoreductase inhibition causes reverse remodeling in rats with dilated cardiomyopathy. Circ Res. 2006 3;98(2):271-9.

17. Ponikowski P, Jankowska EA. Patogenia y presentacio'n clı́nica de la insuficiencia cardiaca aguda. Rev Esp Cardiol. 2015;68: 331-7.

18. Leyva F, Anker SD, Godsland IF, Teixeira M, Hellewell PG, Kox WJ, et al. Uric acid in chronic heart failure: a marker of chronic inflammation. Eur Hear J. 1998;19:1814-22.

19. Anker SD, Doehner W, Rauchhaus M, Sharma R, Francis D, Knosalla $C$, et al. Uric acid and survival in chronic heart failure: validation and application in metabolic, functional, and hemodynamic staging. Circulation. 2003 22;107(15):1991-7.

20. Krishnan E. Gout and the risk for incident heart failure and systolic dysfunction. BMJ Open. 2012;2(1):e000282.

21. Patetsios P, Song M, Shutze WP, Pappas C, Rodino W, Ramirez $\mathrm{JA}$, et al. Identification of uric acid and xanthine oxidase in atherosclerotic plaque. Am J Cardiol. 2001;88(2):188-91.

22. Athyros VG, Elisaf M, Papageorgiou AA, Symeonidis AN, Pehlivanidis AN, Bouloukos VI, et al. Effect of statins versus untreated dyslipidemia on serum uric acid levels in patients with coronary heart disease: a subgroup analysis of the GREek Atorvastatin and Coronaryheart-disease Evaluation (GREACE) study. Am J Kidney Dis. 2004;43: 589-99 GREACE Study Collaborative Group.

23. Hoieggen A, Alderman MH, Kjeldsen SE, Julius S, Devereux RB, De Faire U, et al. LIFE Study Group. The impact of serum uric acid on cardiovascular outcomes in the LIFE study. Kidney Int. 2004 65(3):1041-9.

24. Raja R, Kavita F, Amreek F, Shah A, Sayeed KA, Sehar A. Hyperuricemia Associated with Thiazide Diuretics in Hypertensive Adults. Cureus. 2019 22;11(8):e5457. 